\title{
Evaluation of some micronutrients in patients infected with Giardia lamblia in Hawler city
}

\begin{tabular}{ccc}
\hline Hawre Mustafa bakre* & Salar Adnan Ahmed** & Sharmeen Qadir Faqi*** \\
\hline Abstract &
\end{tabular}

Background and objective: The micro aerophilic flagellated protozoan parasite, Giardia lamblia, is the most common intestinal pathogen infecting human and a major diarrheal disease found throughout the world. It can cause acute or chronic diarrhea contributing to nutritional status, growth, and intellectual function. This prospective study evaluated the association between giardiasis and blood minerals disorders in Hawler city.

Methods: The present study was carried out at the College of Medicine, Hawler Medical University, via collaborating study between the Department of Biochemistry and the Department of Microbiology. The study was carried out on 50 patients with giardiasis and 65 age and sex matched healthy controls. Examination of fecal samples for detection of Giardia cyst and/or trophozoite was carried out using the direct wet smear, while serum zinc, iron and copper levels were measured for both groups spectrophotometrically using commercial diagnostics kits.

Results: The levels of serum zinc and iron in patients infected with Giardia lamblia were significantly lower $(P<0.01)$ compared to normal healthy control, while the differences in the level of serum copper was significantly higher $(P<0.01)$.

Conclusion: : In the frame of this work we delineate that Giardia lamblia infection had a significant effect on serum trace elements reflected by, significant decrease in serum zinc and iron levels, whereas the level of copper increased too in a statistically significant manner.

Keywords: Giardia lamblia, Parasite, Micronutrients, Zinc, Iron, Copper.

\section{Introduction}

Giardiasis is an infectious disease, usually starts with ingestion of the cysts through contaminated food or water, followed by excystation and release of the trophozoite in the small intestine..$^{1-3}$ It is a dangerous disease that affect children and adults and lead to malabsorbtion syndrome and weight loss in the infected persons. ${ }^{4,5}$ Giardia lamblia has a unique metabolic pathway that allows it to survive and multiply by scavenging nutrients from the host; ${ }^{6}$ which commonly causes acute or chronic diarrhea, abdominal pain, nausea, anorexia, vomiting, flatulence, weight loss and fatigue. However, a significant proportion of infected individuals are completely asymptomatic. ${ }^{7}$ Trophozoites, the active forms of the parasite, colonize the upper small intestine by adhering to the apical surface of the epithelium which leads to malnutrition as well as malabsorption in the infected persons. ${ }^{6,8}$ Once a person becomes infected with Giardia lamblia many biochemical changes are often found during infectious period like alteration in lipid profiles, alteration of some micronutrients, certain enzymes and vitamins. $^{9-12}$ Micronutrients such as iron, chromium, copper, manganese, selenium and zinc are essential cofactors of enzymes and as organizers of the molecular structures of the cell. ${ }^{13,14}$ The main impact of human intestinal parasitic infections is its relation to trace elements and vitamin deficiency, which may have

*Department of microbiology, college of medicine, Hawler Medical University, Erbil, Iraq.

$* *$ Department of clinical biochemistry, college of medicine, Hawler Medical University, Erbil, Iraq.

$* * *$ Central laboratory- Jamhuri Teaching Hospital, Erbil, Iraq. 
effects at the community level as regards work and productivity in adults and learning and school performance in children. ${ }^{15}$ Trace elements regulate metabolic pathways and the immune response, as well as suppress the incidence of various diseases $^{16,17}$. The most important vital elements in the human body are zinc, copper, magnesium and vitamin B12. Zinc is especially vital for the immune system functions and its depletion is associated with decline in lymphocyte and thymus functions. ${ }^{18,19}$ While Iron is needed for a number of highly complex processes that continuously take place on a molecular level and that are indispensable to human life, e.g. the transportation of oxygen around your body, haematopoiesis, conversion of blood sugar to energy, the immune system is dependent on iron for its efficient functioning and physical and mental growth also require sufficient iron levels. ${ }^{20}$ The present study was undertaken to study the changes in the serum level of some trace elements (zinc, iron and copper) in patients with giardiasis in comparison to healthy controls.

\section{Methods}

\section{Subjects}

The present study was carried out from February 2014 to January 2015 by collaboration between the central laboratory in Erbil Teaching Hospital, the Department of Clinical Biochemistry and the Department of Microbiology in the College of Medicine, Hawler Medical University, Iraqi Kurdistan region. The subjects of our study were grouped into patients infected with Giardia lamblia and healthy controls. Sixty five healthy controls who had no clinical evidence of any type of diseases with the mean age 31.03 years, ranging from 18-45 years of age were included in this study. Fifty patients infected with human Giardiasis who registered in the central laboratory of Erbil Teaching Hospital with the mean age 30.53 years, ranging from 20-45 years of age were also included in this study.

\section{Collection of samples}

\section{Stool samples}

Stool samples were collected in sterile clean stool cups from all volunteers. Macroscopic and microscopic diagnosis of the giardia was done immediately after collecting stool samples. Among studied groups, a total of 50 positive cases for Giardia lamblia were enrolled as positive group. The control group consisted of age and sex matched healthy volunteers according to the criteria described in the questionnaire which were obtained from individuals attended the mentioned centers.

\section{Blood samples}

Blood samples $(5 \mathrm{ml})$ were collected via atraumatic antecubital venipuncture into vacutainer tubes. The blood was allowed to clot, and the serum was recovered by centrifugation at $3000 \mathrm{rpm}$ for 15 minutes for removal of any suspended cells. The samples were either used immediately for estimation of serum zinc, iron and copper or kept at about $-20{ }^{\circ} \mathrm{C}$ until further analysis.

\section{Methods}

\section{Detection of Giardia lamblia}

Single stool sample was obtained from each patient in a tightly covered wide mouth plastic container. The containers were labeled with sample numbers, date and name of patients. The stool samples were examined for cysts and/or trophozoites of G.lamblia by direct general stool method using physiological saline. A small amount of fecal specimen was taken and the stool was thoroughly emulsified in saline using an applicator stick. A homogeneous thin film was prepared on each slide by mixing the stool with a drop of normal saline and a cover glass was placed on each preparation then the slides was carefully examined microscopically by the direct smear method for identification of parasites. $^{21}$

\section{Estimation of serum zinc}

Serum zinc was determined for both groups colorimetrically by using 
CENTRONIC GmbH(Germany) kit. $^{22}$ According to Johnsen and Eliasson method, zinc forms with 2-(5-brom-2pyridylazo)-5-(N-propyl-N-Sulfopropylamino)-phenol a red chelated complex. The increase of absorbance can be measured at $560 \mathrm{~nm}$, and is proportional directly to the concentration of total zinc in the sample.

\section{Estimation of serum iron}

Ready made kit BIOLABO reagents-mazy. France; ${ }^{23}$ was employed for estimation of serum iron, according to the method, after dissociation of iron-transferrine bound in acid medium, ascorbic acid reduced $\mathrm{Fe}^{+3}$ into $\mathrm{Fe}^{+2}$. $\mathrm{Fe}^{+3}$ ion then form a colored complex with 3-(2-pyridil)-5-6-difruryl-1,-2,4-triazine disulfonate). Ultimately, the absorbance thus measured at $600 \mathrm{~nm}$ is directly proportional to the amount of iron in the specimen.

\section{Estimation of serum copper}

Serum copper was estimated by colorimetric method using LTA-s.r.I. (Milano -Italy) kit. ${ }^{24}$ During copper estimation, the cupric ions react with chromogen $\mathrm{Di}-\mathrm{Br}$ PAESA forming a blue compound and the colored compound produced is proportional to the copper concentration present in the sample.

\section{Statistical analysis}

Statistical analysis of the results was done using the statistical package for the social sciences (version 19). ${ }^{25}$ Results were expressed as mean \pm S.E. Significance of differences was evaluated by independent t-test. The levels of serum zinc, iron, and copper of normal healthy subjects were compared with those of patients infected with human Giardiasis concerning.
A $P$ value of $\leq 0.05$ was considered statistically significant.

\section{Ethical considerations}

The study was approved by the Research Ethics Committee of the College of Medicine of Hawler Medical University. An informed and written consent was taken from each participant before collection of samples.

\section{Results}

\section{Group I (Giardia negative):}

The results of the present study are presented in Table 1. The mean \pm S.E value for serum zinc was $116 \pm 5.5 \mu \mathrm{g} / \mathrm{dl}$ with a range of variation $55-157 \mu \mathrm{g} / \mathrm{dl}$. The mean $\pm S$.E value of serum iron was $137 \pm 7.3 \mu \mathrm{g} / \mathrm{dl}$ with a range of variation 64-169 $\mu \mathrm{g} / \mathrm{dl}$. The mean \pm S.E value for serum copper was $123 \pm 3.8 \mu \mathrm{g} / \mathrm{dl}$ and the range of variation was $69-155 \mu \mathrm{g} / \mathrm{dl}$.

\section{Group II (Giardia Positive):}

The laboratory parameters of patients infected with Giardia lamblia are shown in Table 1. The mean \pm S.E value for serum zinc was $81 \pm 3.7 \mu \mathrm{g} / \mathrm{dl}$ with a range of variation $43-165 \mu \mathrm{g} / \mathrm{dl}$ and the mean \pm S.E value of serum iron was $97 \pm 6.1 \mu \mathrm{g} / \mathrm{dl}$ with a range of variation $47-172 \mu \mathrm{g} / \mathrm{dl}$. The data analysis indicated statistically significant decrease $(P<0.01)$ in mean concentrations of zinc and iron in sera of patients infected with Giardia lamblia in comparison with normal healthy subjects, as shown in Table 1. The mean \pm S.E value for serum copper was $174 \pm 4.9 \mu \mathrm{g} / \mathrm{dl}$ and the range of variation was $78-203 \mu \mathrm{g} / \mathrm{dl}$. The mean value of copper in sera of patients infected with Giardia lamblia was significantly elevated when compared to the normal healthy subjects (Table 1 ).

Table 1: Details of biochemical parameters of the studied groups.

\begin{tabular}{|c|c|c|c|c|c|}
\hline \multirow[t]{2}{*}{$\begin{array}{l}\text { Substance } \\
\text { assayed }(\mu \mathrm{g} / \mathrm{dl})\end{array}$} & \multicolumn{2}{|c|}{$\begin{array}{l}\text { Group I } \\
\text { Giardia Negative (GN) }\end{array}$} & \multicolumn{2}{|c|}{$\begin{array}{l}\text { Group II } \\
\text { Giardia Positive (GP) }\end{array}$} & \multirow[t]{2}{*}{$P$ value } \\
\hline & Mean \pm S.E & Range & Mean $\pm S . E$ & Range & \\
\hline Zinc (Zn) & $116 \pm 5.5$ & $55-157$ & $81 . \pm 3.7$ & $43-165$ & $<0.01$ \\
\hline Iron (Fe) & $137 \pm 7.3$ & $64-169$ & $97 \pm 6.1$ & $47-172$ & $<0.01$ \\
\hline Copper (Cu) & $123 \pm 3.8$ & 69-155 & $174 \pm 4.9$ & $78-203$ & $<0.01$ \\
\hline
\end{tabular}




\section{Discussion}

Giardiasis is among the most intestinal protozoan disease caused by Giardia genus, is still an important public health problem, mainly in specific geographical areas and among people with specific socio-economic status. ${ }^{23}$ In an attempt to shed light on the most important pathophysiological effect of intestinal parasitic infections (giardiasis protozoan) on certain micronutrients, we assayed a series of serum samples of clinically defined giardiasis, and healthy controls. In the present study we found that the patients infected with Giardia lamblia had significantly lower serum zinc level in comparison with healthy controls. The results on serum zinc levels in present study were in accordance with the other worker. ${ }^{12,26-28}$ In addition, our study clearly showed that the mean serum iron level was significantly lower in patients with giardiasis compared to the control group. This finding is similar to that found by other investigators. $^{6,14,29}$ The exact mechanism of micronutrient deficiency (zinc and iron) in giardiasis is not clear. A number of interacting factors are thought to be responsible. Giardia trophozoites attach to the microvillus-covered surface of the duodenum and jejunum. The attachment process damages microvilli, causes villous atrophy, reduces the gut absorptive capacity malabsorption. Anorexia and weight loss are common symptoms in giardiasis patients, and it is well accepted that the lower the protein energy intake, the lower the zinc and iron intake. ${ }^{10,30,31} \mathrm{Giardia}$ lamblia surface antigenic variation is another factor that interferes with the solubility and bioavailability of minerals. The variant-specific surface proteins (VSPs) are a distinct family of cysteine-rich proteins which contain a putative metalbinding domain, the putative binding motif bound $\mathrm{Zn}^{2+}$ in the intestine which may contribute to $\mathrm{Zn}^{2+}$ malnutrition or inhibition of metal-dependent intestinal enzymes, which would lead to malabsorption, a wellknown consequence of giardiasis. ${ }^{32,33}$
Whereas iron deficiency in patients with giardiasis is due to malabsorption, which is generally seen if there is important alteration of the intestinal epithelium. ${ }^{10,14}$ The mean serum copper level in Giardia positive group was significantly higher than that of the control group. The results of serum copper level in the present study were in accordance with the reports from other workers. ${ }^{16,19}$ The exact mechanism responsible for increased copper levels in giardiasis is still unknown. This increase could possibly be explained by increase of copper containing enzyme systems. It has been known that $\mathrm{Cu}$ is an essential trace element within immune functions, that plays a role in immune response against parasites. ${ }^{34}$ It is also known that serum $\mathrm{Cu}$ concentration is maintained within a narrow range by the small intestine and kidney which both affect their fractional absorption under conditions of $\mathrm{Cu}$ deprivation. ${ }^{30,34}$

\section{Conclusion}

This study revealed that there is a significant influence of Giardia lamblia infection on serum trace elements in infected individuals. Further investigations into the nature of alterations in the other trace elements of plasma and a great number of cases may provide a basis for better understanding of the probable effects of moderate or asymptomatic giardiasis on nutrient absorption and status, as well as, the mechanism responsible for it in the patients infected with Giardia lamblia.

\section{Conflicts of interest}

The authors report no conflicts of interest.

\section{References}

1. Halliez M, Buret AG. Extra-intestinal and long term consequences of Giardia duodenalis infections. World J Gastroenterol 2013; 19(47):8974-5.

2. Kilic E, Saraymen R, Miman O, Yazar S. Evaluation of serum copper level during Giardia intestinalis infection. Afr J Microbiol Res 2010; 4:1013-5.

3.Langford TD, Housley MP, Boes M, Chen J, Kagnoff MF, Gillin FD, et al. Central Importance of Immunoglobulin A in host defense against Giardia spp. Infect Immun 2002; 70 (1): 11-8. 
4. Ayeh-Kumi PF, Quarto S, Kwakye-Nuako G, Kretchy JP, Osafo-Kantanka A, Mortu S. Prevalence of Intestinal Parasitic Infections among Food Vendors in Accra, Ghana. J Trop Med Parasitol 2009; 32(1):111-8.

5. Al-Sabbawi MH. Giardiasis in the Third World Countries. J of Chin Clin Med 2007; 2:539-40.

6. Adam RD. Biology of Giardia lamblia. Clin Microbiol Rev 2001; 14:447-75.

7. Bansal D, Harinderpal SB, Rakesh S. Role of cholesterol in parasitic infections. Journal of diabetes and metabolic disorders 2005; 4:10.

8. Huang DB, White AC. An updated review on Cryptosporidium and Giardia. Gastroenterol. Clin North Am 2006; 35:291-314.

9. Demirci M, Delibas N, Altuntas I, Oktem F, Yönden Z. Serum iron, zinc and copper levels and lipid peroxidation in children with chronic giardiasis. J Health Popul Nutr 2003; 21:72-5.

10. Taşkapan C, Atambay M, Aycan. Serum zinc $(\mathrm{Zn})$ levels in patients with giardiosis. Turkiye Parazitol Derg 2007; 31:14-6.

11. Abou-Shady O, El Raziky MS, Zaki MM, Mohamed RK. Impact of Giardia lamblia on growth, serum levels of zinc, copper, and iron in Egyptian children. Biol Trace Elem Res 2011: 140:1-6.

12. Mekhlafi HM, Surin J, Sallam AA, Abdullah AW, Mahdy MA. Giardiasis and poor vitamin: A status among aboriginal school children in rural Malaysia. Am J Trop Med Hyg 2010; 83:523-7.

13. Shenkin A. Micronutrients in health and disease .Postgrade Med J 2006; 82:559-67.

14. Anderson J, Mahan LK. Escott-Stump S. (Eds).Krause Food,Nutrition, and Diet therapy, 10th ed W.B. Saunder Harcourt Brace, Philadelphia; 2000.

15. Hesham MS, Edariah AB, Norhayati M. Intestinal parasitic infections and micronutrient deficiency: A review. Med J Malaysia 2004; 59(2):284-93.

16. Olivares JL, Fernández R, Fleta J, Rodríguez G, Clavel A. Serum mineral levels in children with intestinal parasitic infection. Dig Dis 2003; 21 (3):258-61.

17. Ertan $P$, Ysereli K, Kurt O, Balcioğlu IC, Onağ A. Serological levels of zinc, copper and iron elements among Giardia lamblia infected children in Turkey. Pediatr Int 2002; 44(3):286-88.

18. Culha G, Sangun MK. Serum levels of zinc, copper, iron, cobalt, magnesium and selenium elements in children diagnosed with Giardia intestinalis and Enterobious vermicularis in Hatay,Turkey. Biol Trace Elem Res 2007; 118 (1): 21-26.

19. Kilic E, Yazar S, Saraymen R. Responsiveness of total content changes of magnesium and zinc status in patients infected with Giardia intestinalis. Biol Trace Elem Res 2003; 96(1-3): 153-8.

20. Cook JD, Baynes RD, Skikne BS. Iron Deficiency and the Measurement of Iron Status. Nutrition Research Reviews 1992; 5: 198-202.
21. Garcia LS. Diagnostic Medical Parasitology. 5th ed. Washington, DC: ASM Press; 2007.

22. Johnsen, $R$ eliasson. Evaluation of a commercially available kit for the colorimetric determination of zinc. Int J Androl 1987; 10(2): 435-40.

23. TIETZ NW. Text Book of Clinical Chemistry. $3^{\text {rd }}$ Ed. C.A. Burtis, E.R. ashwood, W.B. Saunders (1999)p. 1698-1704.

24. Pasquinelli F. Diagnostic e Tecniche di Laboratorio, Rossini. 1984, page 1099-1102.

25. Danial WW. Biostatistics: A foundation for analysis in the health science $3^{\text {rd }}$.John wiley, 1983.

26. Quihui L, Morales GG, Méndez RO, Leyva JG, Esparza J, Valencia ME. Could giardiasis be a risk factor for low zinc status in schoolchildren from northwestern Mexico? A cross-sectional study with longitudinal follow-up. BMC Public Health 2010; 10:85.

27. Karakas Z, Demirel N, Tarakcioglu M, Mete N. Serum zinc and copper levels in southeastern Turkish children with giardiasis or amebiasis. Biol Trace Elem Res 2001; 84:11-8.

28. Cheek DB, Mclntosh GH, O'Brien V, Ness D, Green RC. Malnutrition in aboriginal children at Yalata, South Australia. Eur J Clin Nutr 1989; 43: 161-8.

29. Ankarklev J, Jerlstrom-Hultqvist J, Ringqvist E, Troell K, Svard SG. Behind the smile: Cell biology and disease mechanisms of Giardia species. Nat Rev Microbiol 2010; 8:413-22.

30. Nash TE1, Mowatt MR. Variant-specific surface proteins of Giardia lamblia are zinc binding proteins. Proc Natl Acad Sci USA. 1993; 90(12): 5489-93.

31. Buret A, Hardin JA, Olson ME, Gall DG. Pathophysiology of small intestinal malabsorption in gerbils infected with Giardia lamblia. Gastroenterology 1992; 103:506-13.

32. Linder MC, Hazegh-Azam M. Copper biochemistry and molecular biology. Am J Clin Nutr 1996; 63: 797-811.

33. Harris ED. Basic and clinical aspects of $\mathrm{Cu}$. Crit Rev Clin Lab Sci 2003; 40: 547-86.

34. Zarebavani M, Dargahi D, Einollahi N, Dashti N, Mohebali M, Rezaeian M. Serum levels of zinc, copper, vitamin B12, folate and immunoglobulins in individuals with giardiasis. Iran J Public Health 2012; 41(12): 47-53. 